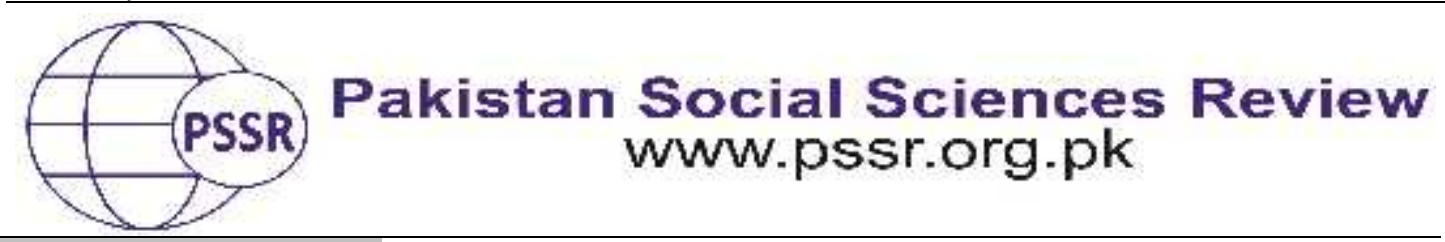

RESEARCH PAPER

\title{
Transformation of Peace Culture: Suggestions for the Universities in Pakistan
}

\author{
Farah Latif Naz ${ }^{1}$ Khalid Khurshid ${ }^{2}$ Farah Deeba ${ }^{3}$
}

1. Lecturer, Department of Education, Bahauddin Zakariya University, Multan, Punjab, Pakistan

2. Charmin, Department of Education, Bahauddin Zakariya University Multan, Punjab, Pakistan

3. Assistant Professor, Department of Education, Bahauddin Zakariya University, Multan, Punjab, Pakistan

\begin{tabular}{|c|c|}
\hline PAPER INFO & ABSTRACT \\
\hline $\begin{array}{l}\text { Received: } \\
\text { March 14, } 2021 \\
\text { Accepted: } \\
\text { May 01, } 2021 \\
\text { Online: } \\
\text { May 15, } 2021\end{array}$ & $\begin{array}{l}\text { The present paper discusses the implacable suggestions for the } \\
\text { transformation of peace culture and sustainable development in } \\
\text { the universities of Pakistan. The recent situation in the } \\
\text { educational institutions especially universities of Pakistan facing } \\
\text { the multiple issues regarding, intolerance and lack of social }\end{array}$ \\
\hline $\begin{array}{l}\text { Keywords: } \\
\text { Culture of Peace, } \\
\text { Higher Education, } \\
\text { Transformation, } \\
\text { Universities }\end{array}$ & $\begin{array}{l}\text { adjustments in the behaviors of the students, this situation } \\
\text { creates unrest in the educational phenomena, the most } \\
\text { challenging issue in the educational universities is the instability } \\
\text { of sustainable development of peace culture, for the solution of } \\
\text { these issues two (02) way technique was adopted, in which one }\end{array}$ \\
\hline $\begin{array}{l}\text { *Corresponding } \\
\text { Author }\end{array}$ & $\begin{array}{l}\text { questionnaire prepared for the university students and other a } \\
\text { semi structure interview was designed for the university } \\
\text { teachers. The sample was collected from four (04) public sector } \\
\text { universities of Pakistan. The results of the data given operational } \\
\text { suggestions, according to the results universities education } \\
\text { system have not any element of creativity and diversity in the } \\
\text { curriculum. So, need to plan creative and value oriented } \\
\text { education for the students, moreover, reasons of cultural } \\
\text { intolerance related with student unions and pressure groups, } \\
\text { these need to address in ethical manners. The current study } \\
\text { suggests to adopt the applicable measure to develop the peaceful } \\
\text { environment in the educational institutions in Pakistan. }\end{array}$ \\
\hline
\end{tabular}

\section{Introduction}

Pires at al., (2020) mentioned that the sustainability in the universities is possible with the transformation of the present situations that is associated with the culture of peace, for this practice tolerance and develop peace among each other and strengthen the people towards unity, the influence of armed forces is not enough to maintain the peace for the promotion of peace culture. 
In this context, Cremin\& Archer (2018) addressed that there is need to develop the sense of awareness for peace and interfaith harmony at individual level. The peace culture is related with vision and this is a gradual process, for the vision need strong leadership with its visionary sight make the peace happened. Moreover, Misra (2020) have opinion that the process of transformation go through the culture of violence to the culture of harmony or peace. This process of transformation required clear vision and sincere dedication for achieving the target. The integrated work for peace helps the future youth to solve the conflicted problems at domestic as well as at national or international level (King, 2020).

Furthermore, Smith \&McCully (2013) added that the role of education and teaching community is crucial because the prevailing situation and violence creates drastic impacts on students. The violence environment does not even effects on the students' physically but also effects on psychological development. Ahmed (2017) observed that in common cases whatever the situation of violence is the most disturbing factor for the population like students and children but this sector is always neglected. Appiah-Thompson (2020) argued that the authorities should consider this factor that students are the future of the nation and the agents of change so the policy makers need to foster the strategies that helps the students to build a peaceful environment.

Moreover, Balvin\& Christie (2020) have view that peace cannot be created because the conflicts are not at surface the conflicts are invisible and are in evitable, with this situation need to deal the conflicts constructively, in this way the education is considered more essential tool to develop values of peace in the students at all levels. Lo Bianco (2016) and Nowotny \& Carrara (2018) stated that peace education now a most emerging field all over the world in the last twentieth century, But due to the unwanted behaviors in developed countries like Pakistan and the false strategies creates crisis in different proportions of the country (Agbedahin, 2019).

\section{Literature Review}

Acaron (2018) stated that instead of solving the conflicts and addressing the issues different governments impose their own vision in the text books. Further, Purohit\&Purohit (2020) have opinion that the present need in this time to address the human issues, the world order work on the development of human peace and wellbeing, this situation can be seen easily in different government text books where has no focused on the privileging issue of the society. Gafurov et al., (2020) added that the overall change in higher education required a practical way pf transformation and there is a need to add peace practices in the courses, in the war and terror situation student's behaviors got affected with intolerance and this situation further develop extremism attitudes in their life. Address these issues with the teaching of values and quality education (Moller \& Shim, 2019).

Moreover, Zhang \& Hon(2020) described that the prevailing situation much stressed on the role of the change agents, that are teachers and students both have the demanding roles for the creation of desired environment in the society (Oueijan, 
2018). Teachers with diverse techniques develop the cohesive vision among the students. Furthermore, Holtorf (2018) added that the students apply those skills in the job market; the factors of empathy and tolerance are correlated with the peaceful cultural society. In the view of Ashraf \&Rafique (2020) that the basic values and the given knowledge in the educational institutions especially in the universities associated with tolerance and this concept further contributed more effectively for the transformation of peace culture, with the visionary planning and adjustment of social paradigms change is possible. The ongoing check and measures creates a healthy environment in the educational settings (Kadiwal\&Durrani, 2018).

In addition, Saleem (2017) have opinion that for the transformation of any situation the fundamental elements are linked with the social inter consistency, after that Arif (2020) also added the same view in term of students' attitudes are result of social and religious thinking and the reason of intolerance found in the base line of unethical practices, these practice received from unreliable sources and caused of frustration and disturbed the social equilibrium of the overall community. Moreover, Tajik (2015) and Kester (2017) have opinion that role of civil society and United Nations also doing their tremendous efforts for the promotion of peace building and transform the university culture into harmony and with positive attributes.

Furthermore, Halai \& Durrani(2018) observed that teachers are the agents of peace, their efforts and skillful teachings develop the social cohesion in the universities of Pakistan. The peace building process required continuous and united strategies of all the educational stakeholders. The main peacemaking agents are teachers and students, the administrative planning need to focus on the collaboration of these elements for the development of strong cultural values in the educational institutions (Bjorkdahl\&Kappler, 2017).

\section{Material and Methods}

In this research study the questionnaire of mixed items were used because this technique of constructing the questions is suitable for this research, in this way for the data collected both qualitative and quantitative ways to check better responses of the respondents. For quantitative analysis questionnaire was designed for the teachers and students that based on two dimensions first one check their opinions and the viewpoints about the peace and peace culture and the second section of the questionnaire was used to get qualitative in which the views of the respondents were explored regarding the suggestion for the transformation of peace culture on the universities, Moreover, the data was analyzedwith SPSS and ANVIVO with word count technique and themes were drawn.

\section{The Population of the Study}

The population of the study was all the students of the public sector universities of Pakistan and the teachers (6829) of public sector universities, the total population of the universities are (85) and the target population of the universities 
are public sector universities that are (21) universities in all the provinces of Pakistan.

\section{Sampling}

In this research the simple random sampling technique was used for the selection of the university students and for the selection of the teachers the convenient sampling technique was used. The total number of universities in Pakistan are 85 where in Punjab (33), in Sind(22) in KPK (24). Baluchistan (06), in this research only Public sector universities were taken as the target sample, and the from the target sample four (04) public sector universities were taken as the sample of the study.

In this study from three (3) provinces, four (04)public universities (Punjab: 02, KPK, 01 and Sindh, 01) were selected. From different disciplines, out of total public sector university students, 270 students of BS (Bachelors of Science) were taken as the sample, out of total population of the public sector university teachers seventy seven (77) teachers (lecturers, Assistance Professor, Associate Professor, Professors) were selected as sample by convenient sampling technique.

\section{Tool of the Research}

In this study two (02) tools were developed, for quantitative analysis a questionnaire was designed for the students of the universities. The qualitative data was taken with the help of semi structural interview questions that were taken from the university teachers.

\section{Results and Discussion}

Quantitative Analysis (students)

Table 1

Gender wise distribution of the university students

\begin{tabular}{ccc}
\hline Gender & Frequency & Percentage (\%) \\
\hline Male & 146 & 17.0 \\
\hline Female & 124 & 83.0 \\
\hline Total & $\mathbf{2 7 0}$ & $\mathbf{1 0 0 . 0}$
\end{tabular}

The above table 1 depicts the overall number of the respondents in which male students were (146) and female students (124) were taken as the sample for this research. These students were selected from different social sciences departments, the overall sample were taken from the four public sector universities of Pakistan. The ration of the sample tries to balance to get the maximum opinions of the overall gender representation. 
Table 2

Involvement of any peace and creative activity in the university

\begin{tabular}{ccc}
\hline Options & Frequency & Percentage (\%) \\
\hline Not at all & 54 & 20.0 \\
\hline Rarely & 56 & 20.7 \\
\hline Sometimes & 116 & 43.0 \\
\hline Frequently & 37 & 13.7 \\
\hline Very frequently & 7 & 2.6 \\
\hline Total & $\mathbf{2 7 0}$ & $\mathbf{1 0 0 . 0}$
\end{tabular}

The table 2 reflects that the involvement of the university students in different activities, in this most of the respondents were involved sometimes (43\%) in the creative and peace related activities and just (16\%) university students have frequently and very frequently involved in the creative activities. Whereas the results also shows that (54\%) students have not any type of creative activities in the university.

Moreover, the results show that creative and peace related activities are rare in the educational institutions; creative activities boost the individual to work for the self-development and for the social straightness.

Table 3:

Who did you contact first for assistance when you had any conflict in the class?

\begin{tabular}{ccc}
\hline Options & Frequency & Percentage (\%) \\
\hline Teachers & 112 & 41.5 \\
\hline Friends & 120 & 44.4 \\
\hline Head of Department & 28 & 10.4 \\
\hline Others & 10 & 3.7 \\
\hline Total & $\mathbf{2 7 0}$ & $\mathbf{1 0 0 . 0}$
\end{tabular}

Table 3 displays that students in the time of any conflict where to prefer for solving the matters, the majority of the students $(44.4 \%)$ respond that they connect with their friends in time of any problem or difficulty have faced on the life or in the university, only $(10 \%)$ students rely on the leadership or concern with the head of the departments. (41\%) students have responded that they connect also with teachers. Further, the results shows that as compare to teachers and heads of the departments, in time of any conflicted difficulty students prefer their friends are more reliable.

Table 4

Most important factor of intolerance in universities (1 to 8)

\begin{tabular}{ccc}
\hline Categories & Frequency & Percent (\%) \\
\hline Students Union & 58 & 21.48 \\
\hline Lack of justice & 35 & 12.96 \\
\hline Peer threats & 25 & 9.27 \\
\hline
\end{tabular}




\begin{tabular}{ccc}
\hline Administrative attitude & 29 & 10.74 \\
\hline Cultural Difference & 41 & 15.19 \\
\hline Male and female Friendships & 26 & 9.62 \\
\hline Freedom of sexual access & 25 & 9.26 \\
\hline Teachers Negative Behavior & 31 & 11.48 \\
\hline Total & $\mathbf{2 7 0}$ & $\mathbf{1 0 0}$ \\
\hline
\end{tabular}

Table 4 shows the most influencing factors of intolerance in the universities, that are ranked one to eight numbers, the majority of the students were considered that $(21.48 \%)$ influencing factor is student union, further, the second factor is related with cultural differences (15.19\%) majority have opinion that the different cultural differences also create short temperament among the students, other respondents considered the third factor is that lake of justice $(12.96 \%)$, due to the negligence of law and order the environment of the universities are disturbed badly, the other remaining factors are the administrative behaviors and teacher negative attitudes also create frustration and intolerance in the behaviors of the university students.

Moreover, the peer threats, freedom of sexual access in the universities also create intolerance, this further linked with the male and female friendships in the educational settings, these factors influence the cultural peace.

Table 5

Affecting Factors of sustainable peace development (1 to 8)

\begin{tabular}{ccc}
\hline Categories & Frequency & Percent (\%) \\
\hline Lack of moral training & 43 & 15.92 \\
\hline Extra curricula Activities & 26 & 9.63 \\
\hline Multi-cultural students & 32 & 11.85 \\
\hline Inappropriate teaching & 39 & 14.44 \\
\hline Power groups & 41 & 15.18 \\
\hline Misuse of Social Media & 35 & 12.96 \\
\hline Political influence & 28 & 10.37 \\
\hline Man Empowerment & 26 & 9.63 \\
\hline Total & $\mathbf{2 7 0}$ & $\mathbf{1 0 0}$
\end{tabular}

The given table 5 indicated the factors that are importance for the sustainable peace development in the universities, these factors were ranked by the university students, majority of the respondents were agree that due to the lack of moral training $(15.92 \%)$ and due to the power groups $(15.18 \%)$, are the hurdles for the development sustainable peace culture in the universities. Others were opinion that the inappropriate teaching $(14.44 \%)$ and misuse of the social media $(12.96 \%)$ create unrestful environment in the educational sectors. Political influences and multicultural students also have the reason for the development of peace culture.

So there is need to address all these factors for the sustainable peace cultural development in the universities. 


\section{Qualitative Analysis (Teachers)}

The qualitative data was analyzed with the help of word counts that are most of the time were delivered in the time of taking opinions of the teachers on the semistructured interview,

Table 6

Suggestions for the transformation of peace culture in universities

\begin{tabular}{cccc}
\hline S.\# & Suggestions & Frequency & Percent (\%) \\
\hline 1 & Students develop peace & 23 & 13.45 \\
\hline 2 & Trainings of peace students/teachers & 12 & 7.01 \\
\hline 3 & Changings in Curriculum/courses & 10 & 5.85 \\
\hline 4 & Peace workshops/activities & 17 & 9.95 \\
\hline 5 & Cultural Activities & 22 & 12.86 \\
\hline 6 & Value related education & 21 & 12.28 \\
\hline 7 & Stop unions and politics & 24 & 14.03 \\
\hline 8 & Arrange creative activities & 10 & 5.84 \\
\hline 9 & Check on social media / mobile phones & 17 & 9.94 \\
\hline 10 & visit to other cultural areas & 15 & 8.77 \\
\hline
\end{tabular}

The table 6 identifies different viewpoints of the respondents' teachers for the transformation of peace culture in the universities of Pakistan. All the views converted in the word shapes and count them. The most frequently spoken words have high percentages that are provide the needed suggestions for the development of peace in the educational institutions.

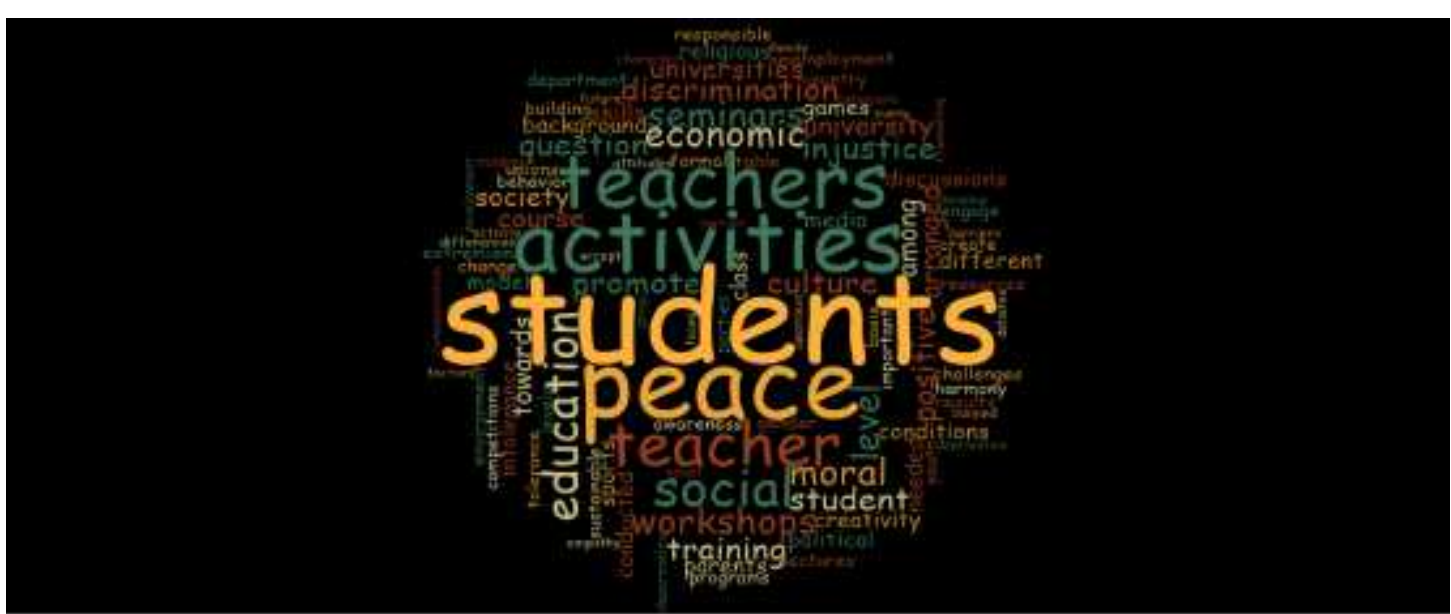

Figure 1

Word counts regarding suggestions for the transformation of peace culture

\section{Themes of the study}

The above table 6 was indicated the themes that were selected with the help of figure 1 that is drawn with the help of word count technique, the suggestions and 
different viewpoints of the respondents regarding the transformation pf peace culture in the universities of Pakistan, with these themes, the qualitative analysis of this study present different opinions that are collect with the word counts, as majority of the respondents were in favor of that students are responsible for the transformation of peace culture (13.45 \%)the help of moral training for the students in the lectures and classrooms,

Training for peace $(7.01 \%)$, for teachers and students, is also needed, other have responses that the hangings in Curriculum (5.85\%) and courses that have peace concepts can transform the peace culture, some have suggested that peace workshops and activities $(9.95 \%)$ helps to create peace awareness among the students, and cultures activities (12.86 \%) in which disseminate the concepts of respect for other cultures present with lectures, some respondents have views that value oriented education $(12.28 \%)$ develop the overall peaceful environment in which give education on morals and respect of other humanity, universities further planned to stop student unions and politic pressures $(14.03 \%)$ from the universities. The arrangements of creative activities (5.84 \%) in the universities shift the negative attitudes in productive skills. Other suggested that check on social media and mobile phones $(9.94 \%)$ also helps to make peace, educate the individuals about the positive use of social media, for the transformation of peace culture universities arrange trips and visit to other cultural areas $(8.77 \%)$. These operational strategies and suggestions help to transform the current peace situation in the universities.

\section{Discussion}

In this study the results shows that there are different factors involved for the development of peace culture in the universities of Pakistan, In the words of Johnson (2019) and Purcell (2019) that the conflicts are associated with the internal factors and these internal factors provide the way of solution and resolving the issues, the method of transformation could found when these internal factors address accordingly. Moreover, the view point of Svensson \& Loat (2019) also have the opinion that are associated with the present study, the social and cultural agreements are kinked with the social and structural sustainability this concept further influence in the educational sectors. However, Pillay (2019)have the same opinion that strengthen this study that the sustainable peace development is strongly associated with the educational leadership, it is the more connected power that have the strength to track the conflicted paradigms in the aligned way. This mean that there are different practicable activities and strategies with the adoption of these strategies the overall working of society increased with community guideline and theses setting bring change in the academic structure (Manzoor, 2020).

\section{Conclusion}

The conclusions were drawn on the bases of results, as the responses from the student side based on the multiple factors. Furthermore, the effects of the educational and economical settings affect the peace culture and the sustainable transformation in the universities. The public sector universities need to develop 
creative and values related activities, further, need to implement strict laws for the violation of any discipline. The check and balance from the administration and the role of teachers are very crucial for the creation of balance and harmonious culture in the universities. In the educational settings and in the classes need to educate harmony. It is important for the youth and community, moreover, this study gave opinion to transform the concept of the students with positive behavioral attitudes towards the different cultures in the universities.

Furthermore, the respondents gave practical suggestions for the development of peace culture in the universities, the observation on the behaviors of the student's helps to resolve the conflicted and violence related culture from the universities. Majority of the respondents were agree that due to the pressure groups in term of student unions or political pressures gave birth to intolerance and unrest situations in the educational environment. The arrangements of positive activities and lectures on moral related concepts help to create lawful culture. The accountability process of all individual create stable scenario. More than this the concept of peace is also related with different cultural and social adjustments. Respondents of the research also indicated that education at higher level institutions also need to add the social issues in the educational lectures and these issue also related to the social integration and cohesion. Other related factors, like discrimination, favoritism, gender issues, religious extremism, ethnic intolerance, sect biasness these are all the prevailing factors need to transform them in the present situations. The overall stricture of the universities planned to develop the moral virtues and character education, this education resolved the existing cultural conflicts and further related issues in harmonious way.

\section{Recommendations}

The results of the present study showed that the transformation of peace culture has a pivotal need for the sustainability in the educational institutions. The above conclusions of this study have some recommendations that are further required for peace culture development and enhance the all the sectors of universities in Pakistan

1. Universities should focuse on the personality and moral development of the students and take initiatives for arranging the workshops and conferences to promote the concept of peace culture in broader way.

2. Faculty in public and private sector universities add ethical and creative concepts in the classrooms while during lectures.

3. University leadership and management need to improve the transparency in the administrative matters for the creation of justice and harmony in the universities.

4. Regular faculty training programs related to develop the positive behaviors of teachers and students inter-relationship need to arrange.

5. More researches should be conducted that will help to find out the conflicted issues in the educational sectors. 


\section{References}

Acaron, T. (2018). Movement decision-making in violence prevention and peace practices. Journal of Peace Education, 15(2), 191-215.

Agbedahin, A. V. (2019). Sustainable development, Education for Sustainable Development, and the 2030 Agenda for Sustainable Development: Emergence, efficacy, eminence, and future. Sustainable Development, 27(4), 669-680.

Ahmed, Z. S. (2017). Peace education in Pakistan. Washington, DC: United States Institute of Peace.

Appiah-Thompson, C. (2020). The concept of peace, conflict and conflict transformation in African religious philosophy. Journal of Peace Education, 17(2), 161-185.

Arif, M., Nadeem, T., \& Ali, M. Q. (2020). Students' Tolerance Level and Their Social and Religious Practices at University Level in Pakistan. Al-Qalam, 25(1.), 471-487.

Ashraf, A. D. M. N., \&Rafique, N. (2020). Tolerance, Peace and Social Cohesion among University Students of Pakistan: A Qualitative Assessment, Pakistan Social Sciences Review, Vol. 4, No. III [117-130]

Balvin, N., \& Christie, D. J. (2020). Children and Peace: From Research to Action, Springer Nature.

Bjorkdahl, A., \&Kappler, S. (2017). Peacebuilding and spatial transformation: Peace, space and place. Taylor \& Francis.

Cremin, H., \& Archer, T. (2018). Transrational Education: Exploring Possibilities for Learning about Peace, Harmony, Justice and Truth in the Twenty First Century. In Transrational resonances (pp. 287-302). Palgrave Macmillan, Cham.

Gafurov, I. R., Safiullin, M. R., Akhmetshin, E. M., Gapsalamov, A. R., \&Vasilev, V. L. (2020). Change of the Higher Education Paradigm in the Context of Digital Transformation: From Resource Management to Access Control. International Journal of Higher Education, 9(3), 71-85.

Halai, A., \&Durrani, N. (2018). Teachers as agents of peace? Exploring teacher agency in social cohesion in Pakistan. Compare: a journal of comparative and international education, 48(4), 535-552.

Holtorf, C. (2018). Embracing change: how cultural resilience is increased through cultural heritage. World archaeology, 50(4), 639-650.

Johnson, A. T. (2019). University infrastructures for peace in Africa: The transformative potential of higher education in conflict contexts. Journal of Transformative Education, 17(2), 173-194. 
Kadiwal, L., \&Durrani, N. (2018). Youth negotiation of citizenship identities in Pakistan: Implications for global citizenship education in conflict-contexts. British Journal of Educational Studies, 66(4), 537-558.

Kester, K. (2017). The case of educational peacebuilding inside the United Nations universities: A review and critique. Journal of Transformative Education, 15(1), 5978.

King, E. W. (2020). Educating for peace in a global society. Intercultural Education, 31(4), 493-498.

Lo Bianco, J. (2016). UNICEF EAPRO-Suggestions for UNICEF EAPRO strategy (20162020) on multilingual education and social cohesion. The University of Melbourne

Manzoor, T., Sarwar, M., \& Shah, A. A. (2020). The Analysis of Peace Teaching Practices at the University Level in Pakistan. sjesr, 3(3), 117-127.

Misra, K. S. (2020). Peace Education: A Challenge for Educators. Horizon, 2(2), 9-14.

Möller, F., \& Shim, D. (2019). Visions of peace in international relations. International Studies Perspectives, 20(3), 246-264.

Nowotny, J. J., \&Carrara, M. (2018). The use of restorative practices to reduce prison gang violence: Lessons on transforming cultures of violence. Conflict Resolution Quarterly, 36(2), 131-144.

Oueijan, H. N. (2018). Educating for peace in higher education. Universal Journal of Educational Research, 6(9), 1916-1920.

Pillay, D. (2019). Peace Leadership: Self-Transformation to Peace. Peace Research, 51(1), 125-135.

Pires, S. M., Nicolau, M., Mapar, M., Dias, M. F., Horta, D., Nicolau, P. B. \&Malandrakis, G. (2020). How to integrate sustainability teaching and learning in higher education Institutions? from context to action for transformation towards SDGs implementation: a literature review.

Purcell, W. M., Henriksen, H., \& Spengler, J. D. (2019). Universities as the engine of transformational sustainability toward delivering the sustainable development goals:"Living labs" for sustainability. International Journal of Sustainability in Higher Education.

Purohit, R., \&Purohit, K. (2020). World Peace and World Unity: A Most Emergent Need of the Present and Future. Journal of Humanities and Social Sciences Studies, 2(6), 64-69. 
Saleem, A. (2017). University Leaders' Perceptions and Contextual Realities for Encouraging Intercultural and Multicultural Harmony in Higher Education Institutions Sindh-Pakistan. FWU Journal of Social Sciences, 11(2).

Smith, R., \&McCully, A. (2013). Organisational self-evaluation and teacher education for community relations in a transforming society? European Journal of Teacher Education, 36(3), 320-345.

Svensson, P. G., \& Loat, R. (2019). Bridge-building for social transformation in sport for development and peace. Journal of Sport Management, 33(5), 426-439.

Tajik, M. A. (2015). Role of civil society institutions in promoting diversity and pluralism in Chitral District of Khyber Pakhtunkhwa, Pakistan.

Zhang, J., \& Hon, H. W. (2020). Towards responsible digital transformation. California Management Review, 62(3). 